\title{
Enhanced Cellular Uptake of H-Chain Human Ferritin Containing Gold Nanoparticles
}

\author{
Italo Moglia ${ }^{1,2}$, Margarita Santiago ${ }^{3}$, Simon Guerrero ${ }^{2,4} \mathbb{D}^{\mathbb{D}}$, Mónica Soler ${ }^{5} \mathbb{D}$, Alvaro Olivera-Nappa ${ }^{3,5, *}$ and \\ Marcelo J. Kogan 1,2,*iD
}

1 Department of Pharmacological and Toxicological Chemistry, Faculty of Chemical and Pharmaceutical Sciences, University of Chile, Santiago 8380494, Chile; italo.moglia@gmail.com

2 ACCDiS-Advanced Center for Chronic Diseases, Faculty of Chemical and Pharmaceutical Sciences, University of Chile, Santiago 8380494, Chile; simon.daiblogt@gmail.com

3 CeBiB - Center for Biotechnology and Bioengineering, Faculty of Physical and Mathematical Sciences, University of Chile, Santiago 8370456, Chile; santiago.margarita@gmail.com

4 Interdisciplinary Research Institute in Biomedical Science-I3CBSEK, SEK University, Santiago 7520317, Chile

5 Department of Chemical Engineering, Biotechnology and Materials, Faculty of Physical and Mathematical Sciences, University of Chile, Santiago 8380494, Chile; msoler@ing.uchile.cl

* Correspondence: aolivera@ing.uchile.cl (A.O.-N.); mkogan@ciq.uchile.cl (M.J.K.)

\section{check for} updates

Citation: Moglia, I.; Santiago, M.; Guerrero, S.; Soler, M.; Olivera-

Nappa, A.; Kogan, M.J. Enhanced Cellular Uptake of H-Chain Human Ferritin Containing Gold

Nanoparticles. Pharmaceutics 2021, 13, 1966. https://doi.org/10.3390/ pharmaceutics13111966

Academic Editors:

Benjamí Oller-Salvia and

Noriyasu Kamei

Received: 2 October 2021

Accepted: 15 November 2021

Published: 19 November 2021

Publisher's Note: MDPI stays neutral with regard to jurisdictional claims in published maps and institutional affiliations.

Copyright: (C) 2021 by the authors. Licensee MDPI, Basel, Switzerland. This article is an open access article distributed under the terms and conditions of the Creative Commons Attribution (CC BY) license (https:/ / creativecommons.org/licenses/by/ $4.0 /)$.
Abstract: Gold nanoparticles (AuNP) capped with biocompatible layers have functional optical, chemical, and biological properties as theranostic agents in biomedicine. The ferritin protein containing in situ synthesized AuNPs has been successfully used as an effective and completely biocompatible nanocarrier for AuNPs in human cell lines and animal experiments in vivo. Ferritin can be uptaken by different cell types through receptor-mediated endocytosis. Despite these advantages, few efforts have been made to evaluate the toxicity and cellular internalization of AuNP-containing ferritin nanocages. In this work, we study the potential of human heavy-chain $(\mathrm{H})$ and light-chain (L) ferritin homopolymers as nanoreactors to synthesize AuNPs and their cytotoxicity and cellular uptake in different cell lines. The results show very low toxicity of ferritin-encapsulated AuNPs on different human cell lines and demonstrate that efficient cellular ferritin uptake depends on the specific $\mathrm{H}$ or L protein chains forming the ferritin protein cage and the presence or absence of metallic cargo. Cargo-devoid apoferritin is poorly internalized in all cell lines, and the highest ferritin uptake was achieved with AuNP-loaded H-ferritin homopolymers in transferrin-receptor-rich cell lines, showing more than seven times more uptake than apoferritin.

Keywords: ferritin; gold nanoparticles; cellular internalization; cellular viability; theranostics

\section{Introduction}

Gold nanoparticles (AuNP) have great potential as theranostic agents in biomedicine due to their optical, chemical, and biological properties, such as surface plasmon resonance, low chemical reactivity, and reduced cell toxicity. The use of AuNP for cell targeting requires a protective layer that provides biocompatibility and prevents nonspecific adsorption of proteins as protein coronae, which could impart new biological properties impacting nanoparticle reactivity, bioavailability, and pharmacokinetics, and ultimately lead to cytotoxicity or immunotoxicity [1]. Ideally, the protective biocompatible layer must improve circulating half-life and minimize the reticuloendothelial system uptake that rapidly removes nanoparticles from the circulatory system to the liver, spleen, or bone marrow [2].

Different molecules have been evaluated as protective layers or coating agents for AuNPs. For example, polymers such as polyethylene glycol [3], biomolecules such as cysteine [4,5], peptides such as glutathione [6,7], and synthetic peptides [8] and proteins such as bovine serum albumin (BSA) [9-13] and ferritin [14-18] have been used in different biomedical applications. 
The use of ferritin (FT) meets many desirable characteristics for a good coating agent for AuNPs in nanomedical applications. This is mainly due to ferritin's particular quaternary structure, which comprises a tissue-specific mix of 24 subunits of heavy $(\mathrm{H})$ and light (L) chain ferritins, forming a hollow sphere protein complex that can be used as a container for metallic nanoparticles. Both subunit types ( $\mathrm{H}$ or $\mathrm{L})$ have similar amino acid substitutions that confer functions specific to each subunit $[19,20]$. Ferritin is completely biocompatible because it is endogenous to humans; its protein shell provides a highly stable protective layer for inorganic nanoparticle coating [17,21-26], and its cavity has been successfully used as a nanoreactor to prepare monodisperse metallic nanoparticles [18,22,27]. The synthesis of AuNP in ferritins from different origins has been reported using horse spleen FT [14-16], mutant L-chain horse spleen FT [28], H-chain human FT [17,29], mutant H-chain human FT [30], and Archaeoglobus fulgidus FT [26].

Another relevant feature of ferritin for nanoparticle targeting is that it can be uptaken by different cell types and tissues through a receptor-mediated endocytosis process. The primary receptor for ferritin is transferrin receptor-1 (TfR1), expressed in many cell lines [31] and tumor tissues $[32,33]$. Furthermore, two other known receptors interact with ferritin: the Tim2 receptor, expressed on oligodendrocytes [34] and B-cells and in the liver and kidney [35,36], and the Scara-5 receptor, expressed in some specific embryonic kidney cell types (stromal and capsular cells, [37]), the MCF-7 breast cancer cell line [38], and blood-retinal barrier cells [39]. So far, these three ferritin receptors are known to recognize the ferritin H-subunit, except for Scara5, which can also interact with the L-subunit of ferritin [40]. Additionally, ferritin can be genetically modified or chemically conjugated to add cell specificity for different receptors to further enhance specificity or target more than one possible receptor or cell type.

Promising results in biomedical imaging in mice have been observed after tail vein injection of horse spleen ferritin and human H-chain ferritin homopolymer containing NIR fluorescent gold nanoclusters, which acted as excellent fluorescent probes for whole-body imaging, with particular targeting to the kidneys [16,17]. Additionally, horse spleen ferritin containing AuNP targeted to the MCF-7 cancer cell line (by chemical conjugation with 2-amino-2-deoxy-glucose) has shown increased computer tomography contrast enhancement [41]. However, despite these few efforts to evaluate the use of gold nanostructures in ferritin for biomedical imaging, the use of human $\mathrm{H}$ and $\mathrm{L}$ ferritin homopolymers for gold nanoparticle synthesis and the evaluation of their toxicity and internalization in different cell lines are still underexplored aspects that must be addressed.

Considering the potential biomedical use of ferritin as a theranostic agent in humans, we tested both human homopolymers ( $\mathrm{H}$ and $\mathrm{L}$ ) as nanoreactors to synthesize gold nanoparticles. We characterized each FT-AuNP homopolymer and analyzed their cytotoxic effect and ability to be taken up by different cell lines. The results show how the intrinsic characteristics of each homopolymer influence the successful synthesis of AuNPs and reveal that the metallic content provides advantageous properties to the FT-based theranostic agent.

\section{Materials and Methods}

\subsection{Plasmid Construction}

cDNA from colorectal adenocarcinoma (Caco-2) cells, donated by Dr. Tulio Nuñez, was used for the amplification of H-chain ferritin (FTH) and L-chain ferritin (FTL) cDNAs with primers designed based on NCBI reference sequences (NM_002032.3 and NM_000146.4). For subsequent cloning into the bacterial expression plasmid pET-22b, the cDNAs were amplified with primer pairs FTH-F/FTH-R and FTL-F/FTL-R (Table 1), which introduced restriction endonuclease cleavage sites for NdeI and XhoI into the $5^{\prime}$ and $3^{\prime}$ regions, respectively. The sequences of constructed plasmids pET-28a-FTH and pET-28a-FTL were verified by DNA sequencing. 
Table 1. Sequences of primers used in this work with the introduced restriction endonuclease sites.

\begin{tabular}{cc}
\hline Primer Name & Sequence $\mathbf{5}^{\prime}-\mathbf{3}^{\prime}$ \\
\hline FTH-F & TCGCCCATATGACGACCGCGTCCACCTC \\
FTH-R & TTGGTCTCGAGGGAAGTCACCCCACGGCTATG \\
FTL-F & AGCCACATATGAGCTCCCAGATTCGTCAG \\
FTL-R & GGGCCCTCGAGAAGTCGCTGGGCTCAGAAG \\
\hline
\end{tabular}

\subsection{Ferritin Expression and Purification}

Plasmids were transformed into Escherichia coli BL21 DE3, and protein expression was induced by growing the cells in autoinduction media [42] for $20 \mathrm{~h}$ at $25^{\circ} \mathrm{C}$, with shaking at $250 \mathrm{rpm}$. Cells were harvested at $6000 \times \mathrm{g}$ for $10 \mathrm{~min}$, resuspended in $50 \mathrm{mM}$ Tris $\mathrm{pH} 8$, and disrupted by sonication. Clarified supernatants were heated at $75{ }^{\circ} \mathrm{C}$ for $10 \mathrm{~min}$, cooled on ice for $5 \mathrm{~min}$, and denatured protein contaminants were removed by centrifugation. Then, ferritin extracts were purified through a Q-sepharose column eluting with a linear $\mathrm{NaCl}$ gradient (0-1 M) using an ÄKTA Avant system. Ferritin-containing fractions were concentrated and finally purified using a Superdex 200 Increase 10/300 GL column, selecting monomer protein elution for further AuNP synthesis.

\subsection{Gold Nanoparticle Synthesis in Apoferritin}

Gold nanoparticle (AuNP) synthesis was performed following the protocol published by Fan 2010 [15] with slight modifications. Briefly, $13.3 \mu \mathrm{L}$ of a $100 \mathrm{mM}$ solution of $\mathrm{HAuCl}_{4}$ were added to $1 \mathrm{~mL}$ of $2 \mathrm{mg} / \mathrm{mL}$ ferritin solution in Tris $50 \mathrm{mM} \mathrm{pH} 8$ (equivalent to $300 \mathrm{Au}$ atoms per ferritin, $300 \mathrm{Au} / \mathrm{FT}$ ), and the solution was incubated for $2 \mathrm{~h}$ at $4{ }^{\circ} \mathrm{C}$. Afterward, excess metallic salts were removed by dialysis against Tris $50 \mathrm{mM} \mathrm{pH} 8$. A first chemical reduction was performed by adding $13.3 \mu \mathrm{L}$ of a $100 \mathrm{mM}$ solution of $\mathrm{NaBH}_{4}$ and incubating at $4{ }^{\circ} \mathrm{C}$ overnight. The next day, another $13.3 \mu \mathrm{L}$ fraction of $100 \mathrm{mM} \mathrm{HAuCl}_{4}(300 \mathrm{Au} / \mathrm{FT})$ was added to the ferritin solution and incubated for $2 \mathrm{~h}$ at $4{ }^{\circ} \mathrm{C}$. Excess auric salts were removed by dialysis against Tris $50 \mathrm{mM} \mathrm{pH} 8$. A second chemical reduction was performed by adding $13.3 \mu \mathrm{L}$ of a $100 \mathrm{mM}$ ascorbic acid solution and incubating at $4{ }^{\circ} \mathrm{C}$ overnight. Samples were centrifuged at $14,000 \mathrm{rpm}$ for $10 \mathrm{~min}$ at $4{ }^{\circ} \mathrm{C}$. Finally, the soluble fraction was dialyzed against Tris $50 \mathrm{mM} \mathrm{pH} 8$ and stored at $4{ }^{\circ} \mathrm{C}$. Each gold nanoparticle synthesis experiment in ferritin was performed in duplicate.

\subsection{Characterization of Ferritin AuNP}

Protein quantification was carried out using the modified Lowry method (Thermo Fisher), with BSA as a reference. Optical properties of protein samples with nanoparticles were measured using UV-vis spectroscopy in a Lambda 25 spectrophotometer (Perkin Elmer, Waltham, MA, USA). Ferritin samples containing AuNPs were subjected to size exclusion chromatography (SEC) using a Superdex 200 Increase 10/300 GL in an FPLC Äkta Avant instrument (GE Healthcare Life Sciences), measuring absorbance at $280\left(\mathrm{~A}_{280} \mathrm{~nm}\right)$ and $550 \mathrm{~nm}\left(\mathrm{~A}_{550 \mathrm{~nm}}\right)$ for protein and AuNP detection, respectively. Dynamic light scattering (DLS) was used to measure the colloidal size distribution and Z-potential of samples using a Zetasizer Nano instrument (Malvern). The structural integrity of the samples was also characterized by native polyacrylamide gel electrophoresis (PAGE). TEM characterization was performed using a JEM-1010 JEOL microscope operated at $100 \mathrm{KV}$ from the University of Barcelona. The statistical analysis of gold nanoparticle size distribution was performed using ImageJ software by sampling over 400 particles.

\subsection{Cell Culture and Incubation with Ferritin AuNP}

Human colon adenocarcinoma HT29 cells (ATCC), human embryonic kidney HEK293 cells (ATCC), mouse brain cortex BEND3 cells (ATCC), and mouse embryonic fibroblasts 3HC /10T1/2 cells (ATCC) were maintained in Dulbecco's modified Eagle's medium (DMEM HG medium) (Gibco ${ }^{\mathrm{TM}}$; Thermo Fisher Scientific, Waltham, MA, USA) supplemented with $10 \%$ fetal bovine serum (FBS; Bioind) and antibiotics (penicillin $100 \mathrm{UI} / \mathrm{mL}$, 
streptomycin $100 \mu \mathrm{g} / \mathrm{mL}$ ), at $37^{\circ} \mathrm{C}$ in $5 \% \mathrm{CO}_{2}$. For uptake assays, cells were seeded in a 96-well plate at a density of 2500 cells $/ 100 \mu \mathrm{L}$ of medium and incubated for $24 \mathrm{~h}$ with FTH and FTL containing gold nanoparticles or iron oxides (as loading control). ApoFTH and ApoFTL were used as control. The added ferritin samples never exceed $10 \%$ of cell culture volume.

\subsection{Viability Assays}

In order to evaluate cell viability after incubation with ferritin samples containing AuNPs, the medium was replaced with fresh culture medium containing $10 \%$ of tetrazolium compound in an MTS ${ }^{\circledR}$ assay (CellTiter $96{ }^{\circledR}$ Aqueous Non-Radioactive Cell Proliferation Assay), according to the manufacturer's instructions (Promega, Madison, WI, USA). The soluble formazan produced by live cells was detected by absorbance at $490 \mathrm{~nm}$ on a multiscan reader (Synergy-H4, Biotek, VT, USA). Background values contributed by excess cell debris and bubbles obtained by measuring at $650 \mathrm{~nm}$ were subtracted.

\subsection{Fixation and Confocal Microscopy}

Cells were fixed with $4 \%$ paraformaldehyde (PFA) at $4{ }^{\circ} \mathrm{C}$ for $10 \mathrm{~min}$. Then, residual PFA was blocked with $50 \mathrm{mM}$ glycine. Then, cell membranes were permeated with $0.1 \%$ Triton X-100 for $10 \mathrm{~min}$ and blocked with $2 \%$ BSA for $30 \mathrm{~min}$. Next, cells were incubated with a dilution of 1:100 of anti FTL (PA5-29599, Thermo Fisher Scientific, Bedford, MA, USA) or anti FTH (sc-376594, Santa Cruz Biotechnology Inc, Dallas, TX, USA) in 2\% BSA for $1 \mathrm{~h}$ at $37{ }^{\circ} \mathrm{C}$. Then, antibodies were rinsed with $2 \%$ BSA and incubated with 1:300 secondary antibodies (Anti Rabbit Alexa488, ${ }^{\circledR}$ Invitrogen or Anti Mouse Alexa546, ${ }^{\circledR}$ Molecular Probes, Salem, OR, USA). After several rinses, cells were incubated with a 1:2000 DAPI dilution. The cell-containing coverslips were mounted on glass slides using Fluoromount G (Thermo Fisher Scientific, Bedford, MA, USA) for imaging and analysis in a Zeiss confocal microscope. Images were taken using a 63X aqueous lens with glycerol-based immersion medium (IR: 1.4) employing a digital zoom of 0.5X by plane and $1 X$ for $\mathrm{z}$ stacking. Ten different fields of the glass slide with cell homogeneity were measured and quantified using ImageJ software. Cell fluorescence was measured in the region of interest and corrected by integrated density adjusted by mean background fluorescence in the region of interest of the cell area. Mean fluorescence intensity (ROI of Cell Fluorescence Corrected $=$ Integrated Density of ROI (Area of ROI x Mean Fluorescence of Background Readings) of treated cells with metal-containing ferritin was divided by the mean fluorescence of the apoferritin control group and, finally, was registered, plotted and analyzed using GraphPad software.

\section{Results and Discussion}

\subsection{Gold Nanoparticles Synthesis and Characterization}

Recombinant human H-ferritin homopolymer (FTH) and L-ferritin homopolymer (FTL) were used as nanocontainers for the synthesis of AuNPs to obtain FTH-AuNP and FTL-AuNP, respectively, following a protocol with two successive gold addition-reduction steps based in a previous protocol published by Fan 2010 [15] (Figure 1). Potentially, gold nanoparticle growth could occur in the outer or inner surface of the ferritin shell. 


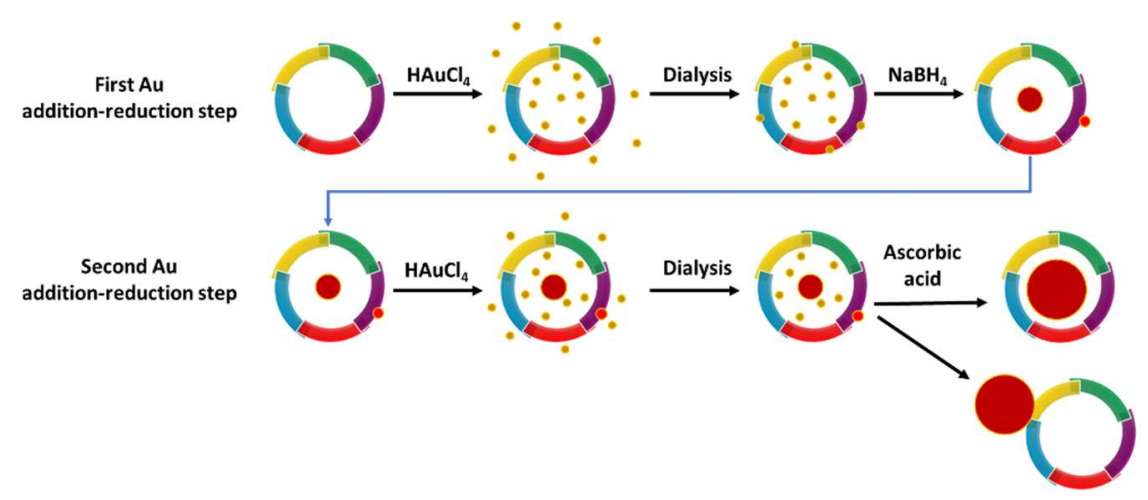

Figure 1. Diagram of the 2-step gold nanoparticle synthesis protocol in recombinant human ferritin. It cannot be discarded that some gold atoms could be on the outer ferritin surface after the first dialysis, giving rise to nanoparticles outside the formation.

Ferritin-containing gold nanoparticles (FT-AuNPs) were characterized by UV-vis spectroscopy in the range of 400 to $800 \mathrm{~nm}$ to evaluate the characteristic surface resonance plasmon (SRP) absorbance peak of the AuNPs [43] (Figure 2). The spectra of FT-AuNP samples exhibited the SRP absorbance peak at 511 and $520 \mathrm{~nm}$ in FTH and FTL, respectively. The slight shift observed between both AuNP-ferritin SRP peaks and the different absorbance intensities between FTH and FTL reflect not only differences in the metallic core size distribution of the gold nanoparticles [44] but also the effect of the dielectric constant of the nanoparticle environment in each homopolymer, which is different due to the specific amino acid composition interacting with the AuNP surface.

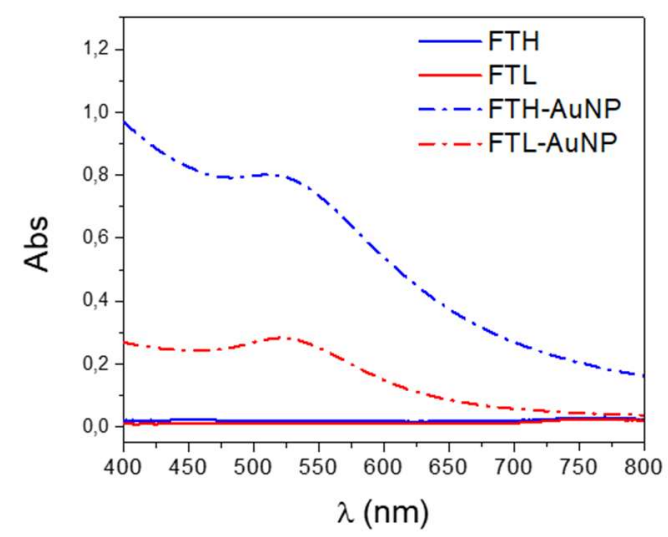

Figure 2. Absorbance spectra of FT-AuNP samples. Gold-containing samples (FTH-Au NP and FTL-Au NP) are represented by dash-and-dot lines to compare them to the apo-forms of FTH and FTL shown as continuous lines.

The FT-AuNP samples were further characterized by studying their structural integrity using size exclusion chromatography (SEC) and dynamic light scattering (DLS). Absorbance at $280 \mathrm{~nm}\left(\mathrm{~A}_{280 \mathrm{~nm}}\right)$ was used in chromatographic analysis to detect the protein and the absorbance at $550 \mathrm{~nm}\left(\mathrm{~A}_{550 \mathrm{~nm}}\right)$ for AuNP detection. The chromatographic characterization of apoferritin homopolymer samples at $280 \mathrm{~nm}$ exhibited two prominent elution peaks for each sample, with a slight difference in elution volumes. The ApoFTH profile showed a first elution peak at $9.1 \mathrm{~mL}$ and a second peak at $10.4 \mathrm{~mL}$. ApoFTL exhibits a broad first protein elution with two overlapping peaks at 8.9 and $9.4 \mathrm{~mL}$ and a second elution peak at $10.8 \mathrm{~mL}$ (Figure 3A). These elution profiles indicate two different subpopulations of ferritin in the original sample that have also been reported by other authors [22,45-47]. The first protein elution peak with a higher molecular weight corresponds to ferritin cage oligomers (dimers or trimers), while the second elution peak contains ferritin cage monomers, corroborated by native PAGE analysis (Figure S1). In a 
previous work of our group, horse spleen ferritin (HSF) showed the same elution profile and hydrodynamic diameter measurement in the SEC collected fractions, with a first elution peak having a mean diameter of $30 \pm 2 \mathrm{~nm}$ (ferritin oligomers) and the second elution peak with a monodisperse diameter of $10 \pm 1 \mathrm{~nm}$ (monomeric ferritin) [46].

(a)

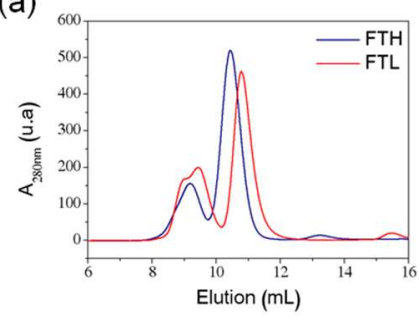

(b)

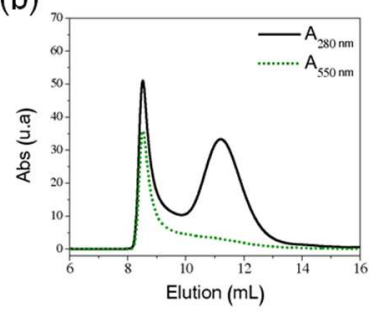

(c)

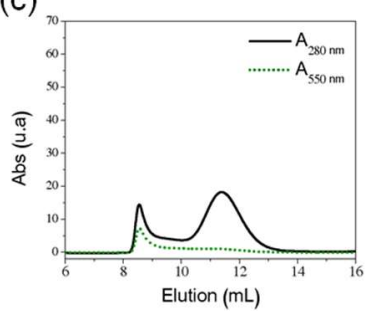

Figure 3. Size exclusion chromatography of FTL and FTH samples. Elution profile of (a) ApoFTH and ApoFTL, (b) FTH-AuNP and (c) FTL-AuNP.

The chromatographic profile of the FTH-AuNP sample $\left(\mathrm{A}_{280 \mathrm{~nm}}\right)$ shows elution peaks at 8.5 and $11.2 \mathrm{~mL}$, while the FTL-AuNP sample shows protein elution peaks at 8.6 and $11.4 \mathrm{~mL}$ (Figure 3B,C, respectively). The absorbance profile of these samples at $550 \mathrm{~nm}$ shows the coelution of AuNPs with the first protein elution peak $(8.5-8.6 \mathrm{~mL})$, which corresponds to the fraction containing oligomeric ferritin species. On the other hand, the lack of absorption at $\mathrm{A}_{550 \mathrm{~nm}}$ in the ferritin monomer elution (second elution peak, 11.2-11.4 mL) suggests that this peak contains apoferritin or ferritin containing gold nanoclusters, which are fluorescent and are undetectable by absorbance measurements [15,48,49].

A semiquantitative analysis of the peak areas from protein chromatograms in Figure 3 suggests that nanoparticle synthesis in ferritin induces changes that alter the monomer/ oligomer ratio present in the initial apoferritin sample (Table 2). This monomer/oligomer ratio is lower for FTH-AuNP (ratio: 1.8), which implies a higher proportion of oligomeric species (fraction associated with AuNP) and, therefore, a higher AuNP synthesis efficiency compared to FTL-AuNP. The FTH homopolymer has a ferroxidase center in each of its 24 subunits that could interact through the imidazole ring of His residues with $\mathrm{Au}^{+3}$ ions [17,50], offering nucleation sites for the further formation of nanostructures. In addition, sulfur-containing amino acids (cysteine and methionine) in the FTH homopolymer could play an essential role in interacting with $\mathrm{Au}^{+3}$ ions $[15,30,51]$. Nanoparticle nucleation and growth in FTL seem to be mediated by Cys126 [28].

Table 2. Monomeric/oligomeric fraction analysis from size exclusion chromatograms.

\begin{tabular}{ccccc}
\hline & Apo FTL & FTL-AuNP & Apo FTH & FTH-AuNP \\
\hline Monomer & $60.1 \%$ & $74.4 \%$ & $73.3 \%$ & $64.3 \%$ \\
\hline Oligomer & $39.9 \%$ & $25.6 \%$ & $26.7 \%$ & $35.7 \%$ \\
\hline Ratio & $1.5: 1$ & $2.9: 1$ & $2.7: 1$ & $1.8: 1$ \\
\hline
\end{tabular}

The measurement of the hydrodynamic diameter $\left(\mathrm{H}_{\mathrm{d}}\right)$ by dynamic light scattering (DLS) of the apoferritin samples displayed an average size near $20 \mathrm{~nm}$, higher than the size of monomeric ferritin (12 nm), confirming the presence of monomeric and oligomeric protein species in the starting material (Table 3). Furthermore, in ferritin-AuNP samples, $\mathrm{H}_{\mathrm{d}}$ values increased, thus reconfirming that AuNP synthesis induces oligomeric protein species, consistent with the results obtained by SEC analysis. Ferritin oligomer formation related to AuNP synthesis was also observed by native PAGE analysis (Figures S1 and S2). 
Table 3. Monomeric/oligomeric fraction analysis from size exclusion chromatograms.

\begin{tabular}{ccc}
\hline Sample & $\mathbf{H}_{\mathbf{d}} \mathbf{( n m )}$ & Z-Pot $(\mathbf{m V} \mathbf{)}$ \\
\hline Apo FTH & $18 \pm 12$ & -13.5 \\
Apo FTL & $20 \pm 9$ & -13.7 \\
FTH-AuNP & $55 \pm 29$ & -10.2 \\
FTL-AuNP & $35 \pm 16$ & -7.6 \\
\hline
\end{tabular}

The net electrostatic charge of folded apoferritin (Z-potential) in Tris-HCl buffer at $\mathrm{pH} 7$ was measured for both types of apo-homopolymer samples, showing a result of nearly $-13 \mathrm{mV}$ (Table 3), representing an overall view of ferritin surface potentials, including contributions from solvent and tightly bound metal. After AuNP synthesis, the Z-potential in both homopolymers decreased to -10.2 and $-7.6 \mathrm{mV}$ for FTH-AuNP and FTL-AuNP, respectively. The net charge decrease is caused by the interaction between the protein with $\mathrm{Au}$ ions, and the lowered electrostatic repulsion between ferritin monomers can trigger the formation of ferritin oligomers. Generally, Z-potential values are not reported in studies involving metallic nanoparticle synthesis in ferritin, making it difficult to compare our results with others. Exceptionally, previous studies showed a decrease in Z-potential and increased $\mathrm{H}_{\mathrm{d}}$ in iron-loaded ferritin compared to apoferritin [46,52,53].

Welch et al. demonstrated that ferritin containing H-chains (FTH) is oxidized during iron loading at its ferroxidase center, and this oxidation results in protein aggregation. The cysteine at position 90, located at the end of the solvent-facing loop, is critical for ferritin aggregate formation during iron loading. Additionally, dityrosine moieties are formed during iron loading, depending on cysteine residue oxidation [54,55]. Our results show that both FTH and FTL form oligomers, suggesting a possible role of the process of AuNP synthesis that could indirectly lead to the oxidation of surface-exposed cysteines.

Another suitable explanation for ferritin oligomerization after AuNP synthesis is that gold interacts with the side chains of certain amino acids, which could potentially induce small changes in the secondary structure of the protein that could affect the external surface of ferritin, somehow decreasing the repulsion between protein nanocages mediated by intermolecular interactions. So far, side-chain conformational changes in the amino acid that interacts with $\mathrm{Au}^{+3}$ or $\mathrm{Au}^{0}$ have been reported [28,51]. In addition, different authors have reported the conservation of the secondary structures of ferritin after iron incorporation to produce magnetoferritin, therefore maintaining the almost intact protein cage after iron mineralization [56-59]. Identical results were reported by Xiangyou Lui et al., revealing that ferritin with $\mathrm{Pt}$ nanoparticles does not have significant changes in the secondary structures of the protein, markedly $\alpha$-helical [60]. On the contrary, Kashanian et al. [61] reported that the synthesis of cobalt nanoparticles inside apoferritin induces an increment of near $9 \%$ in the $\alpha$-helical content and a decrease in the $\beta$-sheet protein structure content, thus altering colloidal stability. Therefore, there is not enough evidence supporting that the formation of oligomeric species after the synthesis of inorganic nanoparticles in ferritin is related to the conformational changes of the secondary structure.

We studied FT-AuNP samples using TEM to measure the gold nanoparticle size distribution of each ferritin homopolymer. AuNPs were directly observed, allowing the measurement of the electron-dense spherical metallic cores, showing that the mean diameter of the nanoparticles was $6 \pm 1.8 \mathrm{~nm}(\mathrm{~N}=833)$ and $5 \pm 1.9 \mathrm{~nm}(\mathrm{~N}=444) \mathrm{nm}$ for FTH-AuNP and FTL-AuNP, respectively (Figure 4). Although these results cannot directly demonstrate that AuNPs are inside ferritin's cavity, the absence of AuNPs with sizes over $9 \mathrm{~nm}$ is evidence that AuNPs could be inside the protein, given that the ferritin cavity has a $\sim 8 \mathrm{~nm}$ size constraint. Additionally, the negative-stained samples of FTH-AuNP (Figure S3) showed some electron-dense cores inside the ferritin structure, which had an unchanged mean diameter of $11.5 \pm 0.8 \mathrm{~nm}(\mathrm{~N}=100)$. No electron-dense cores are observed outside the protein-stained shell. Nevertheless, the presence of Au atoms on the ferritin surface, driving the formation of the observed oligomeric species, cannot be excluded. 
(a)

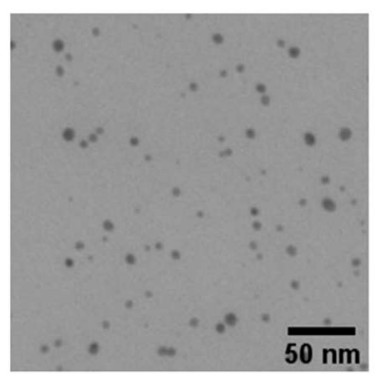

(c)

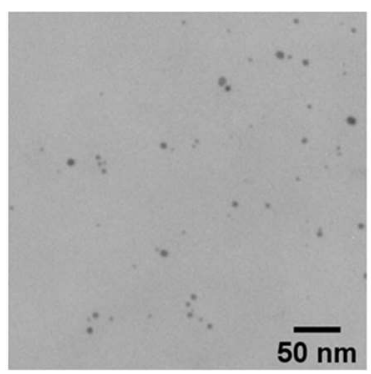

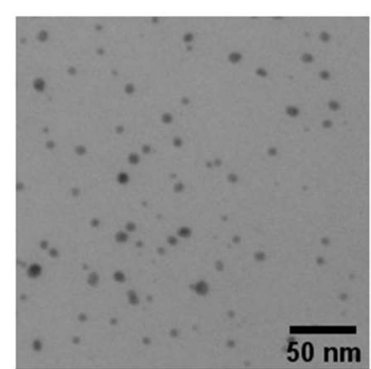

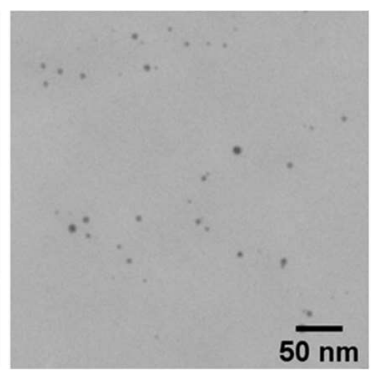

(b)

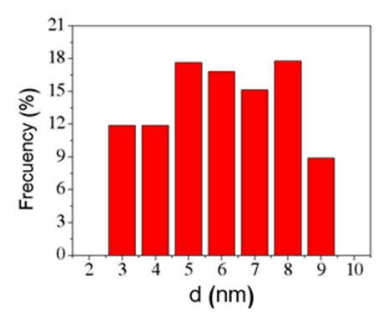

(d)

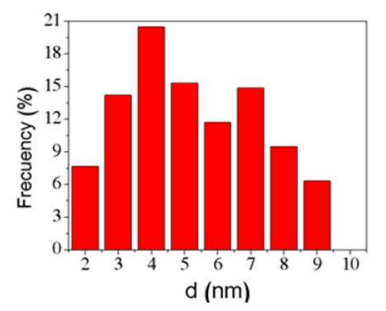

Figure 4. TEM images of FT-AuNP samples without staining. (a) FTH-AuNP, (b) size distribution of FTH-AuNP samples, (c) FTL-AuNP and (d) size distribution of FTL-AuNP samples. Scale bar $200 \mathrm{~nm}$

\subsection{Cell Viability and FT-AuNP Toxicity}

We used a proliferation assay to evaluate cell viability after 24-h incubation with FTH and FTL containing AuNPs. Results indicated that the incubation with the highest concentration of $0.4 \mathrm{mg} / \mathrm{mL}(0.8 \mu \mathrm{M})$ of FT-AuNPs had a minor effect on the viability of human HEK293T cells and murine C3H/10T1/2 cells, considered as healthy control cells (Figure 5). Two other cell lines were tested for viability after incubation with FT-AuNP, colon cancerous HT29 cells, and neural endothelial BEND3 cells. Both showed more sensitivity to the treatment, triggering a reduction of cell viability even at $0.2 \mathrm{mg} / \mathrm{mL}$ of FT-AuNP concentration. However, the viability of these two cell lines after doubling the amount of FT-AuNP never fell below 70\%. The increased toxicity observed in the HT29 and BEND3 lines may be caused by a higher level of internalization, showing accumulation or dose-dependent behavior, as defined by other authors [16,62].

A broad spectrum of toxicities reported for AuNP depends on many factors: shape, size, capping agent, the cell line used in the viability assay, and exposition time, among others [63]. In this study, using ferritin for AuNP capping decreases reactivity, reduces toxicity, and offers a biocompatible carrier. The detected relative toxicity found for FTHAuNP and FTL-AuNP could be considered low when compared to other values reported for AuNP in gold-containing ferritin, which range between $100 \%$ to $90 \%$ viability in SHSY5Y cells (72 h incubation, up to $30 \mu \mathrm{M}$ [29]), Caco-2, and HepG2 cells (12 h incubation, up to $10 \mu \mathrm{M}[16])$. 
(a)

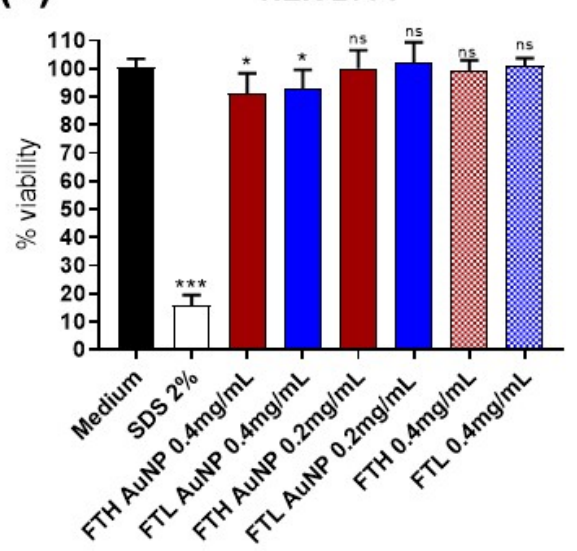

(c)

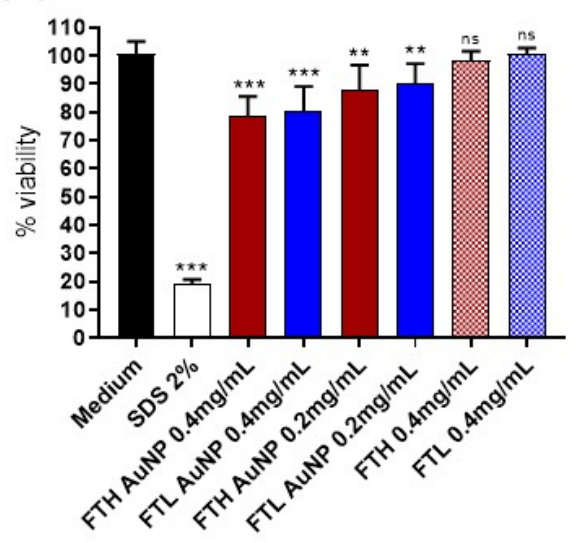

(b)

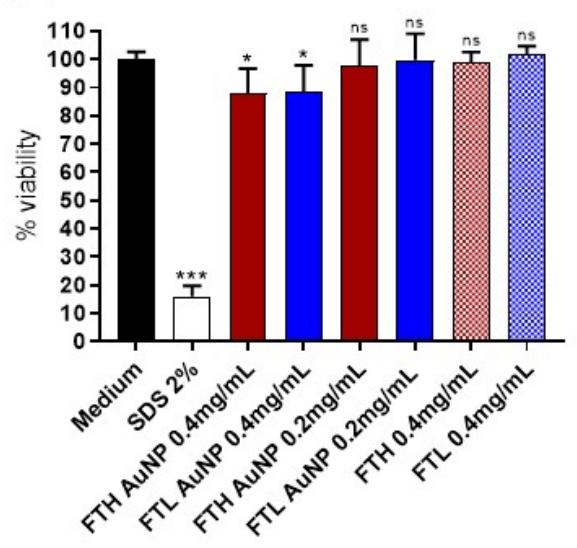

(d)

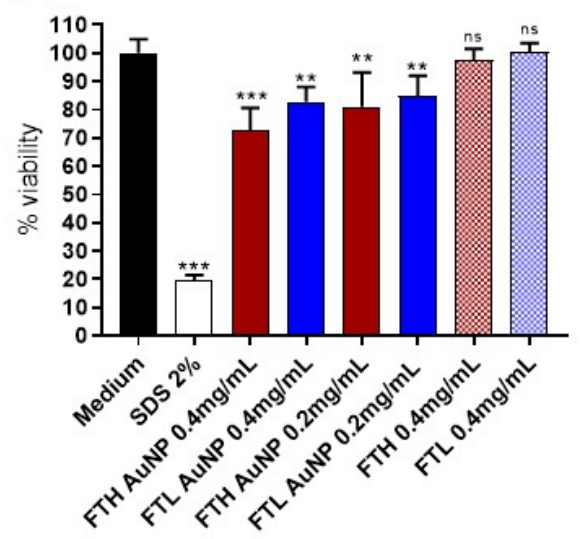

Figure 5. Cell viability after incubation with ferritin Au-NP compared to apoferritin. (a) HEK 293T cell line, (b) C3H/10T1/2 cell lines, (c) BEND3 cell lines, and (d) HT29 cell lines (mean \pm SEM; $n=9 ; 3$ independent experiments with 3 replications each); MTS assay. Data were analyzed using a one-way analysis of variance and Tukey's post hoc test. Statistically significant differences are indicated $\left({ }^{*} p<0.05 ;{ }^{* *} p<0.01 ;{ }^{* * *} p<0.001\right.$; ns, not significant).

\subsection{Cell Uptake of FTH and FTL with Gold Nanoparticles}

The uptake of FT-AuNP by different cell lines was analyzed after $2 \mathrm{~h}$ of incubation by confocal microscopy (Figure 6A). Qualitatively, the uptake of FTH or FTL containing AuNPs was higher compared to apoferritin. This uptake enhancement was also observed for ferritin containing iron oxides (FT-Fe), used as control samples (red channel in Figure 6A). Image quantification corroborated the differences in cell internalization of the ferritin samples, which were consistently higher for ferritins containing AuNPs or iron oxides (Figure 5B). For the HEK 293T cell line, the internalization values varied between 1.1- to 1.8fold more than apoferritin and were similar for both homopolymers and metallic contents (FT-AuNP or FT-Fe). For the C3H/10T1/2 cell line, the FTH homopolymer containing AuNP and Fe showed higher internalization values (between 2.4 and 2.0, respectively) than FTL-AuNP and FTL-Fe (1.9 and 1.6, respectively). In BEND3 and HT29 cell lines, FTH-AuNP was highly internalized, reaching values of 4.9- and 6.4-fold more than FTH, respectively. FTH-Fe also showed increased internalization rates, with values of 3.3- and 4.7-fold more than FTH in BEND3 and HT29, respectively. In these two cell lines, FTL containing AuNP or iron oxides showed a lower uptake increase than FTH, with a 2.8- and 2.2-fold increase over apo-FTL, respectively (Figure 6B). 


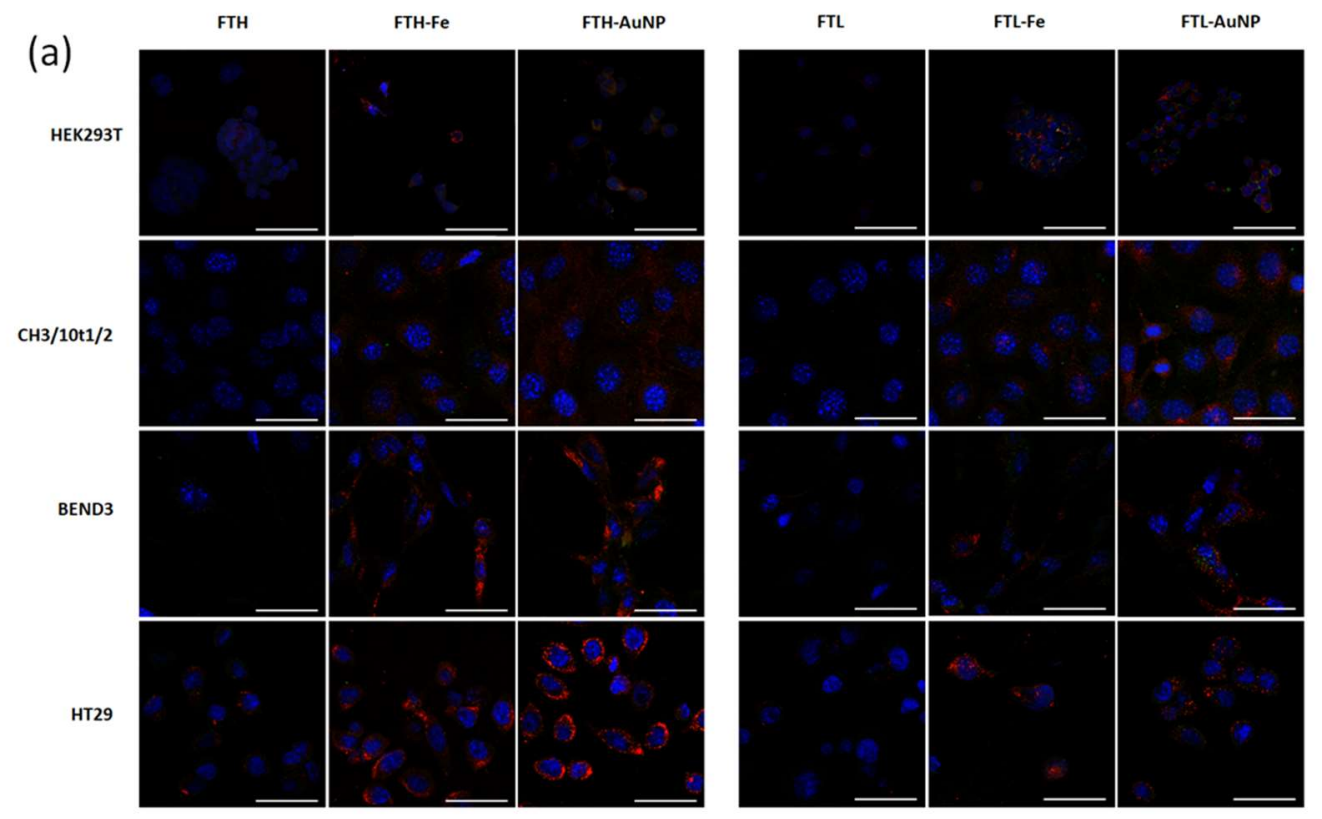

(b)
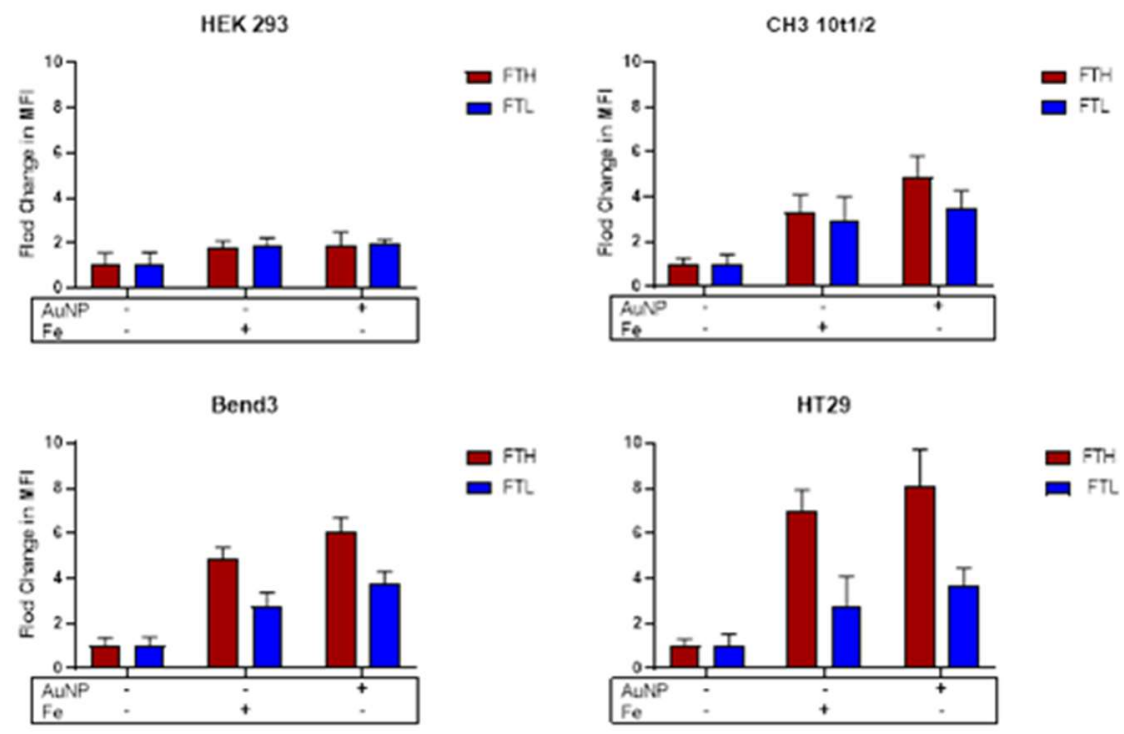

Figure 6. Confocal microscopy results for different cell lines after incubation with FT-AuNP. (a) Confocal images of HEK293T, CH3/10T1/2, BEND3, and HT29 were obtained after incubation for $24 \mathrm{~h}$ with H-ferritin (FTH) and L-ferritin (FTL), with or without AuNP or iron oxides (anti FTH or FTL in red; (DAPI) nucleus in blue; scale bars: $20 \mu \mathrm{m}$ ). (b) Plots representing fold changes in MFI (mean fluorescence intensity) \pm SD from more than three independent experiments.

The differences in uptake between both homopolymers, FTH and FTL, containing either AuNP or iron oxides, can be attributed to the availability of their uptake receptors. H-chains are mainly internalized by transferrin receptor 1 (TR1), which is ubiquitously expressed and overexpressed in cancerous and vascular endothelial cell lines [64]. On the other hand, L-chains are internalized by the SCARA5 receptor, which is less abundant in cells and only expressed in particular cell types $[39,65]$. Our results are in congruence with previous TfR1 expression data for the HEK 293T cell-line, which shows low levels of internalization compared with other cell lines and has been described to have low levels of TfR1 [31,66]. Additionally, the high internalization observed in the BEND3 and HT29 cell lines correlates with the previously reported overexpression of TfR1 in these 
cell lines $[67,68]$. These results are relevant for developing new imaging or drug-delivery systems based on gold-containing ferritin for brain targeting and cancer treatments where cells overexpress transferrin receptors.

Notoriously, metallic content also affects the uptake level of both homopolymers. This observation is best appreciated in cell lines with enhanced uptake, such as BEND3 and HT29, suggesting that apoFTH and apoFTL are poorly internalized by these cell types; however, the same homopolymers with a metallic content are highly internalized, although in a much lower level for FTL. The same behavior has been previously observed by Sunkesula et al. [69], who observed that ferritin iron content modulates its uptake by the intestinal epithelium. However, this is the first time this observation has been made for ferritin with other contents, particularly AuNPs.

Cell internalization of ferritin occurs through receptor-mediated endocytosis (RME), which provides one major pathway for the trafficking of extracellular molecules into the cell. The first step of RME involves the binding of a ligand to a specific cell surface receptor. Circulating ferritin needs to overcome this first step to enter the cell successfully. Thus, the question arising from this investigation is whether there is a difference in receptor binding between apoferritin and holoferritin, in this case, gold-containing ferritin.

Studies comparing apo and holoprotein structures show that, in most cases, the proteins undergo relatively small conformational rearrangements of their tertiary structure upon ligand binding/release (root mean square deviations (RMSDs) of the a-carbon from the native are $<1 \mathrm{~A}^{\circ}$ ) [70]. Clark et al. confirmed an inherently different behavior for backbones and side chains, where backbones tend to show very little conformational change, and side chains are frequently pushed into new conformations upon ligand binding [71]. Additionally, molecular dynamics of apo and holo-proteins indicated that, although the overall protein structure is unchanged by the presence of the ligand, other interaction properties are significantly affected by ligand binding, such as bound waters. This antecedent suggests that binding thermodynamics depend not simply on ligand interactions with a small subset of protein atoms but dynamically on the range of motions coupling water, protein, and ligand molecules [72,73].

Future work should be directed towards a better understanding of how metallic content interacts with ferritin to induce an enhancement in its cellular uptake.

\section{Conclusions}

When comparing the two human ferritin homopolymers, FTH and FTL, our results demonstrate that AuNP can be synthesized in both, but nanoparticle synthesis in FTH gives slightly bigger nanoparticles and is more efficient than FTL. In addition, FTH-AuNP has a higher degree of cellular uptake in three of the cell lines tested compared to FTLAuNP, which correlates with previously reported TfR1 expression in these lines. Inorganic content (AuNP or iron oxides) enhances both homopolymers' cellular internalization, especially in FTH, and AuNP has a higher effect on internalization rates than iron oxides in our study. In summary, we show that cellular ferritin uptake seems to depend on three independent factors: (a) the protein chain forming the ferritin cage (and probably the ratio between chains for heteropolymeric ferritins), (b) the presence or absence of metallic cargo within ferritin, and (c) the presence and abundance of specific receptors on the cell membrane. The highest ferritin uptake was achieved using AuNP-loaded heavy-chain ferritin homopolymers in transferrin-receptor-rich cell lines, while apoferritin is always poorly internalized.

Supplementary Materials: The following are available online at https:/ /www.mdpi.com/article/ 10.3390/pharmaceutics13111966/s1, Figure S1: Native PAGE of ferritin samples, Figure S2: FTHAuNP SEC chromatogram (a) and Native PAGE of elution fractions (b), Figure S3: TEM analysis for FTH-AuNP samples with negative staining.

Author Contributions: Conceptualization, M.J.K. and A.O.-N.; Methodology, M.S. (Margarita Santiago), I.M. and S.G.; Investigation, M.S. (Margarita Santiago), I.M. and S.G.; Resources, M.J.K. and 
A.O.-N.; Writing-Original Draft Preparation, I.M., M.S. (Margarita Santiago) and S.G.; WritingReview and Editing, M.J.K., M.S. (Mónica Soler), and A.O.-N.; Funding Acquisition, M.J.K. and A.O.-N. All authors have read and agreed to the published version of the manuscript.

Funding: This research was funded by Fondap 15130011, Fondecyt 1211482, Postdoctorate-Fondecyt 3190297, Fondecyt PIA FB0001 (CeBiB - Centre for Biotechnology and Bioengineering), Fondequip EQM160157 and EQM 170111.

Institutional Review Board Statement: Not applicable.

Informed Consent Statement: Not applicable.

Data Availability Statement: The data presented in this study are available on request from the corresponding author.

Acknowledgments: The authors would like to acknowledge Tulio Nuñez for Caco2 cDNA, University of Barcelona, for allocating TEM usage time. The graphical abstract was created using BioRender.com (27 September 2021).

Conflicts of Interest: The authors declare no conflict of interest.

\section{References}

1. Barbero, F.; Russo, L.; Vitali, M.; Piella, J.; Salvo, I.; Borrajo, M.L.; Busquets-Fité, M.; Grandori, R.; Bastús, N.G.; Casals, E.; et al. Formation of the Protein Corona: The Interface between Nanoparticles and the Immune System. Semin. Immunol. 2017, 34, 52-60. [CrossRef]

2. Nie, S. Understanding and Overcoming Major Barriers in Cancer Nanomedicine. Nanomedicine 2010, 5, 523-528. [CrossRef]

3. Wuelfing, P.; Gross, S.M.; Miles, D.T.; Murray, R.W. Nanometer Gold Clusters Protected by Surface-Bound Monolayers of Thiolated Poly(ethylene Glycol) Polymer Electrolyte. J. Am. Chem. Soc. 1998, 120, 12696-12697. [CrossRef]

4. Luthuli, S.D.; Chili, M.M.; Revaprasadu, N.; Shonhai, A. Cysteine-Capped Gold Nanoparticles Suppress Aggregation of Proteins Exposed to Heat Stress. IUBMB Life 2013, 65, 454-461. [CrossRef] [PubMed]

5. Saw, W.S.; Ujihara, M.; Chong, W.Y.; Voon, S.H.; Imae, T.; Kiew, L.V.; Lee, H.B.; Sim, K.S.; Chung, L.Y. Size-Dependent Effect of Cystine/citric Acid-Capped Confeito-like Gold Nanoparticles on Cellular Uptake and Photothermal Cancer Therapy. Colloids Surf. B Biointerfaces 2018, 161, 365-374. [CrossRef] [PubMed]

6. Harper, B.; Sinche, F.; Wu, R.H.; Gowrishankar, M.; Marquart, G.; Mackiewicz, M.; Harper, S.L. The Impact of Surface Ligands and Synthesis Method on the Toxicity of Glutathione-Coated Gold Nanoparticles. Nanomaterials 2014, 4, 355-371. [CrossRef] [PubMed]

7. Sousa, A.A.; Morgan, J.T.; Brown, P.H.; Adams, A.; Jayasekara, M.P.S.; Zhang, G.; Ackerson, C.J.; Kruhlak, M.J.; Leapman, R.D. Synthesis, Characterization, and Direct Intracellular Imaging of Ultrasmall and Uniform Glutathione-Coated Gold Nanoparticles. Small 2012, 8, 2277-2286. [CrossRef]

8. Slocik, J.M.; Stone, M.O.; Naik, R.R. Synthesis of Gold Nanoparticles Using Multifunctional Peptides. Small 2005, 1, 1048-1052. [CrossRef]

9. Murawala, P.; Phadnis, S.M.; Bhonde, R.R.; Prasad, B.L.V. In Situ Synthesis of Water Dispersible Bovine Serum Albumin Capped Gold and Silver Nanoparticles and Their Cytocompatibility Studies. Colloids Surf. B Biointerfaces 2009, 73, 224-228. [CrossRef] [PubMed]

10. Rastogi, L.; Kora, A.J.; Arunachalam, J. Highly Stable, Protein Capped Gold Nanoparticles as Effective Drug Delivery Vehicles for Amino-Glycosidic Antibiotics. Mater. Sci. Eng. C Mater. Biol. Appl. 2012, 32, 1571-1577. [CrossRef] [PubMed]

11. Lillo, C.R.; Calienni, M.N.; Rivas Aiello, B.; Prieto, M.J.; Rodriguez Sartori, D.; Tuninetti, J.; Toledo, P.; Alonso, S.D.V.; Moya, S.; Gonzalez, M.C.; et al. BSA-Capped Gold Nanoclusters as Potential Theragnostic for Skin Diseases: Photoactivation, Skin Penetration, in Vitro, and in Vivo Toxicity. Mater. Sci. Eng. C Mater. Biol. Appl. 2020, 112, 110891. [CrossRef] [PubMed]

12. Khullar, P.; Singh, V.; Mahal, A.; Dave, P.N.; Thakur, S.; Kaur, G.; Singh, J.; Singh Kamboj, S.; Singh Bakshi, M. Bovine Serum Albumin Bioconjugated Gold Nanoparticles: Synthesis, Hemolysis, and Cytotoxicity toward Cancer Cell Lines. J. Phys. Chem. C 2012, 116, 8834-8843. [CrossRef]

13. Nghiem, T.H.L.; Nguyen, T.T.; Fort, E.; Nguyen, T.P.; Hoang, T.M.N.; Nguyen, T.Q.; Tran, H.N. Capping and in Vivo Toxicity Studies of Gold Nanoparticles. Adv. Nat. Sci: Nanosci. Nanotechnol. 2012, 3, 015002.

14. Shin, Y.; Dohnalkova, A.; Lin, Y. Preparation of Homogeneous Gold-Silver Alloy Nanoparticles Using the Apoferritin Cavity as a Nanoreactor. J. Phys. Chem. C Nanomater. Interfaces 2010, 114, 5985-5989. [CrossRef]

15. Fan, R.; Chew, S.W.; Cheong, V.V.; Orner, B.P. Fabrication of Gold Nanoparticles inside Unmodified Horse Spleen Apoferritin. Small 2010, 6, 1483-1487. [CrossRef] [PubMed]

16. Sun, C.; Yang, H.; Yuan, Y.; Tian, X.; Wang, L.; Guo, Y.; Xu, L.; Lei, J.; Gao, N.; Anderson, G.J.; et al. Controlling Assembly of Paired Gold Clusters within Apoferritin Nanoreactor for in Vivo Kidney Targeting and Biomedical Imaging. J. Am. Chem. Soc. 2011, 133, 8617-8624. [CrossRef] [PubMed] 
17. Sun, C.; Yuan, Y.; Xu, Z.; Ji, T.; Tian, Y.; Wu, S.; Lei, J.; Li, J.; Gao, N.; Nie, G. Fine-Tuned H-Ferritin Nanocage with Multiple Gold Clusters as near-Infrared Kidney Specific Targeting Nanoprobe. Bioconjug. Chem. 2015, 26, 193-196. [CrossRef] [PubMed]

18. Monti, D.M.; Ferraro, G.; Petruk, G.; Maiore, L.; Pane, F.; Amoresano, A.; Cinellu, M.A.; Merlino, A. Ferritin Nanocages Loaded with Gold Ions Induce Oxidative Stress and Apoptosis in MCF-7 Human Breast Cancer Cells. Dalton Trans. 2017, 46, 15354-15362. [CrossRef]

19. Wang, Z.; Gao, H.; Zhang, Y.; Liu, G.; Niu, G.; Chen, X. Functional Ferritin Nanoparticles for Biomedical Applications. Front. Chem. Sci. Eng. 2017, 11, 633-646. [CrossRef]

20. Zhang, C.; Zhang, X.; Zhao, G. Ferritin Nanocage: A Versatile Nanocarrier Utilized in the Field of Food, Nutrition, and Medicine. Nanomaterials 2020, 10, 1894. [CrossRef]

21. Domínguez-Vera, J.M.; Colacio, E. Nanoparticles of Prussian Blue Ferritin: A New Route for Obtaining Nanomaterials. Inorg. Chem. 2003, 42, 6983-6985. [CrossRef]

22. Moglia, I.; Santiago, M.; Soler, M.; Olivera-Nappa, A. Silver Nanoparticle Synthesis in Human Ferritin by Photochemical Reduction. J. Inorg. Biochem. 2020, 206, 111016. [CrossRef]

23. Kasyutich, O.; Ilari, A.; Fiorillo, A.; Tatchev, D.; Hoell, A.; Ceci, P. Silver Ion Incorporation and Nanoparticle Formation inside the Cavity of Pyrococcus Furiosus Ferritin: Structural and Size-Distribution Analyses. J. Am. Chem. Soc. 2010, 132, 3621-3627. [CrossRef] [PubMed]

24. Wang, Z.; Huang, P.; Jacobson, O.; Wang, Z.; Liu, Y.; Lin, L.; Lin, J.; Lu, N.; Zhang, H.; Tian, R.; et al. Biomineralization-Inspired Synthesis of Copper Sulfide-Ferritin Nanocages as Cancer Theranostics. ACS Nano 2016, 10, 3453-3460. [CrossRef] [PubMed]

25. Fan, J.; Yin, J.-J.; Ning, B.; Wu, X.; Hu, Y.; Ferrari, M.; Anderson, G.J.; Wei, J.; Zhao, Y.; Nie, G. Direct Evidence for Catalase and Peroxidase Activities of Ferritin-platinum Nanoparticles. Biomaterials 2011, 32, 1611-1618. [CrossRef] [PubMed]

26. Pulsipher, K.W.; Honig, S.; Deng, S.; Dmochowski, I.J. Controlling Gold Nanoparticle Seeded Growth in Thermophilic Ferritin Protein Templates. J. Inorg. Biochem. 2017, 174, 169-176. [CrossRef] [PubMed]

27. Mosca, M.; Hong, J.; Hadeler, E.; Hakimi, M.; Brownstone, N.; Liao, W.; Bhutani, T. Psoriasis and Cardiometabolic Comorbidities: An Evaluation of the Impact of Systemic Treatments in Randomized Clinical Trials. Dermatol. Ther. 2021, 11, 1497-1520. [CrossRef]

28. Maity, B.; Abe, S.; Ueno, T. Observation of Gold Sub-Nanocluster Nucleation within a Crystalline Protein Cage. Nat. Commun. 2017, 8, 14820. [CrossRef]

29. Mosca, L.; Falvo, E.; Ceci, P.; Poser, E.; Genovese, I.; Guarguaglini, G.; Colotti, G. Use of Ferritin-Based Metal-Encapsulated Nanocarriers as Anticancer Agents. NATO Adv. Sci. Inst. Ser. E Appl. Sci. 2017, 7, 101. [CrossRef]

30. Butts, C.A.; Swift, J.; Kang, S.-G.; Di Costanzo, L.; Christianson, D.W.; Saven, J.G.; Dmochowski, I.J. Directing Noble Metal Ion Chemistry within a Designed Ferritin Protein. Biochemistry 2008, 47, 12729-12739. [CrossRef]

31. Li, L.; Fang, C.J.; Ryan, J.C.; Niemi, E.C.; Lebrón, J.A.; Björkman, P.J.; Arase, H.; Torti, F.M.; Torti, S.V.; Nakamura, M.C.; et al. Binding and Uptake of H-Ferritin Are Mediated by Human Transferrin Receptor-1. Proc. Natl. Acad. Sci. USA 2010, 107, 3505-3510. [CrossRef]

32. Daniels, T.R.; Delgado, T.; Rodriguez, J.A.; Helguera, G.; Penichet, M.L. The Transferrin Receptor Part I: Biology and Targeting with Cytotoxic Antibodies for the Treatment of Cancer. Clin. Immunol. 2006, 121, 144-158. [CrossRef] [PubMed]

33. Tortorella, S.; Karagiannis, T.C. Transferrin Receptor-Mediated Endocytosis: A Useful Target for Cancer Therapy. J. Membr. Biol. 2014, 247, 291-307. [CrossRef] [PubMed]

34. Todorich, B.; Zhang, X.; Slagle-Webb, B. Tim-2 Is the Receptor for H-ferritin on Oligodendrocytes. J. Neurochem. 2008, 107, 1495-1505. [CrossRef]

35. Chen, T.T.; Li, L.; Chung, D.-H.; Allen, C.D.C.; Torti, S.V.; Torti, F.M.; Cyster, J.G.; Chen, C.-Y.; Brodsky, F.M.; Niemi, E.C.; et al. TIM-2 Is Expressed on B Cells and in Liver and Kidney and Is a Receptor for H-Ferritin Endocytosis. J. Exp. Med. 2005, 202, 955-965. [CrossRef] [PubMed]

36. Han, J.; Seaman, W.E.; Di, X.; Wang, W.; Willingham, M.; Torti, F.M.; Torti, S.V. Iron Uptake Mediated by Binding of H-Ferritin to the TIM-2 Receptor in Mouse Cells. PLoS ONE 2011, 6, e23800. [CrossRef] [PubMed]

37. Li, J.Y.; Paragas, N.; Ned, R.M.; Qiu, A.; Viltard, M.; Leete, T.; Drexler, I.R.; Chen, X.; Sanna-Cherchi, S.; Mohammed, F.; et al. Scara5 Is a Ferritin Receptor Mediating Non-Transferrin Iron Delivery. Dev. Cell 2009, 16, 35-46. [CrossRef]

38. Geninatti Crich, S.; Cadenazzi, M.; Lanzardo, S.; Conti, L.; Ruiu, R.; Alberti, D.; Cavallo, F.; Cutrin, J.C.; Aime, S. Targeting Ferritin Receptors for the Selective Delivery of Imaging and Therapeutic Agents to Breast Cancer Cells. Nanoscale 2015, 7, 6527-6533. [CrossRef] [PubMed]

39. Mendes-Jorge, L.; Ramos, D.; Valença, A.; López-Luppo, M.; Pires, V.M.R.; Catita, J.; Nacher, V.; Navarro, M.; Carretero, A.; Rodriguez-Baeza, A.; et al. L-Ferritin Binding to scara5: A New Iron Traffic Pathway Potentially Implicated in Retinopathy. PLoS ONE 2014, 9, e106974. [CrossRef]

40. Yu, B.; Cheng, C.; Wu, Y.; Guo, L.; Kong, D.; Zhang, Z.; Wang, Y.; Zheng, E.; Liu, Y.; He, Y. Interactions of Ferritin with Scavenger Receptor Class A Members. J. Biol. Chem. 2020, 295, 15727-15741. [CrossRef] [PubMed]

41. Aslan, T.N.; Aşık, E.; Güray, N.T.; Volkan, M. The Potential Application of Gold-Apoferritin Nanocages Conjugated with 2-Amino-2-Deoxy-Glucose for Imaging of Breast Cancer Cells. J. Biol. Inorg. Chem. 2020, 25, 1139-1152. [CrossRef] [PubMed]

42. Studier, F.W. Protein Production by Auto-Induction in High Density Shaking Cultures. Protein Expr. Purif. 2005, 41, 207-234. [CrossRef] 
43. Huang, X.; El-Sayed, M.A. Gold Nanoparticles: Optical Properties and Implementations in Cancer Diagnosis and Photothermal Therapy. J. Adv. Res. 2010, 1, 13-28. [CrossRef]

44. Bastús, N.G.; Comenge, J.; Puntes, V. Kinetically Controlled Seeded Growth Synthesis of Citrate-Stabilized Gold Nanoparticles of up to 200 Nm: Size Focusing versus Ostwald Ripening. Langmuir 2011, 27, 11098-11105. [CrossRef] [PubMed]

45. Keyes, J.D.; Hilton, R.J.; Farrer, J.; Watt, R.K. Ferritin as a Photocatalyst and Scaffold for Gold Nanoparticle Synthesis. J. Nanopart. Res. 2011, 13, 2563-2575. [CrossRef]

46. Moglia, I.; Santiago, M.; Olivera-Nappa, Á.; Soler, M. An Optimized Low-Cost Protocol for Standardized Production of Iron-Free Apoferritin Nanocages with High Protein Recovery and Suitable Conformation for Nanotechnological Applications. J. Inorg. Biochem. 2018, 183, 184-190. [CrossRef]

47. Petrucci, O.D.; Hilton, R.J.; Farrer, J.K.; Watt, R.K. A Ferritin Photochemical Synthesis of Monodispersed Silver Nanoparticles That Possess Antimicrobial Properties. J. Nanomater. 2019, 1-8. [CrossRef]

48. Yang, Y.; Han, A.; Li, R.; Fang, G.; Liu, J.; Wang, S. Synthesis of Highly Fluorescent Gold Nanoclusters and Their Use in Sensitive Analysis of Metal Ions. Analyst 2017, 142, 4486-4493. [CrossRef] [PubMed]

49. Xie, J.; Zheng, Y.; Ying, J.Y. Protein-Directed Synthesis of Highly Fluorescent Gold Nanoclusters. J. Am. Chem. Soc. 2009, 131, 888-889. [CrossRef]

50. Jiang, X.; Sun, C.; Guo, Y.; Nie, G.; Xu, L. Peroxidase-like Activity of Apoferritin Paired Gold Clusters for Glucose Detection. Biosens. Bioelectron. 2015, 64, 165-170. [CrossRef]

51. Maity, B.; Hishikawa, Y.; Lu, D.; Ueno, T. Recent Progresses in the Accumulation of Metal Ions into the Apo-Ferritin Cage: Experimental and Theoretical Perspectives. Polyhedron 2019, 172, 104-111. [CrossRef]

52. Melníková, L.; Mitróová, Z.; Timko, M.; Kováč, J.; Avdeev, M.V.; Petrenko, V.I.; Garamus, V.M.; Almásy, L.; Kopčanský, P. Structural Characterization of Magnetoferritin. Mendeleev Commun. 2014, 24, 80-81. [CrossRef]

53. Balejcikova, L.; Molcan, M.; Kovac, J.; Kubovcikova, M.; Saksl, K.; Mitroova, Z.; Timko, M.; Kopcansky, P. Hyperthermic Effect in Magnetoferritin Aqueous Colloidal Solution. J. Mol. Liq. 2019, 283, 39-44. [CrossRef]

54. Welch, K.D.; Van Eden, M.E.; Aust, S.D. Modification of Ferritin during Iron Loading. Free Radic. Biol. Med. 2001, 31, 999-1006. [CrossRef]

55. Welch, K.D.; Reilly, C.A.; Aust, S.D. The Role of Cysteine Residues in the Oxidation of Ferritin. Free Radic. Biol. Med. 2002, 33, 399-408. [CrossRef]

56. Yang, C.; Cao, C.; Cai, Y.; Xu, H.; Zhang, T.; Pan, Y. Effects of PEGylation on Biomimetic Synthesis of Magnetoferritin Nanoparticles. J. Nanopart. Res. 2017, 19, 101. [CrossRef]

57. Cai, Y.; Cao, C.; He, X.; Yang, C.; Tian, L.; Zhu, R.; Pan, Y. Enhanced Magnetic Resonance Imaging and Staining of Cancer Cells Using Ferrimagnetic H-Ferritin Nanoparticles with Increasing Core Size. Int. J. Nanomedicine 2015, 10, $2619-2634$.

58. Cao, C.; Wang, X.; Cai, Y.; Sun, L.; Tian, L.; Wu, H.; He, X.; Lei, H.; Liu, W.; Chen, G.; et al. Targeted In Vivo Imaging of Microscopic Tumors with Ferritin-Based Nanoprobes across Biological Barriers. Adv. Mater. 2014, 26, 2566-2571. [CrossRef]

59. Koralewski, M.; Balejčíková, L.; Mitróová, Z.; Pochylski, M.; Baranowski, M.; Kopčanský, P. Morphology and Magnetic Structure of the Ferritin Core during Iron Loading and Release by Magnetooptical and NMR Methods. ACS Appl. Mater. Interfaces 2018, 10, 7777-7787. [CrossRef] [PubMed]

60. Liu, X.; Wei, W.; Wang, C.; Yue, H.; Ma, D.; Zhu, C.; Ma, G.; Du, Y. Apoferritin-Camouflaged Pt Nanoparticles: Surface Effects on Cellular Uptake and Cytotoxicity. J. Mater. Chem. 2011, 21, 7105-7110. [CrossRef]

61. Kashanian, S.; Abasi Tarighat, F.; Rafipour, R.; Abbasi-Tarighat, M. Biomimetic Synthesis and Characterization of Cobalt Nanoparticles Using Apoferritin, and Investigation of Direct Electron Transfer of Co(NPs)-Ferritin at Modified Glassy Carbon Electrode to Design a Novel Nanobiosensor. Mol. Biol. Rep. 2012, 39, 8793-8802. [CrossRef]

62. Lv, C.; Yin, S.; Zhang, X.; Hu, J.; Zhang, T.; Zhao, G. 16-Mer Ferritin-like Protein Templated Gold Nanoclusters for Bioimaging Detection of Methylmercury in the Brain of Living Mice. Anal. Chim. Acta 2020, 1127, 149-155. [CrossRef] [PubMed]

63. Alkilany, A.M.; Murphy, C.J. Toxicity and Cellular Uptake of Gold Nanoparticles: What We Have Learned so Far? J. Nanopart. Res. 2010, 12, 2313-2333. [CrossRef]

64. De Vico, G.; Martano, M.; Maiolino, P.; Carella, F.; Leonardi, L. Expression of Transferrin Receptor-1 (TFR-1) in Canine Osteosarcomas. Vet. Med. Sci 2020, 6, 272-276. [CrossRef]

65. Conti, L.; Lanzardo, S.; Ruiu, R.; Cadenazzi, M.; Cavallo, F.; Aime, S.; Geninatti Crich, S. L-Ferritin Targets Breast Cancer Stem Cells and Delivers Therapeutic and Imaging Agents. Oncotarget 2016, 7, 66713-66727. [CrossRef] [PubMed]

66. Wang, J.; Tian, S.; Petros, R.A.; Napier, M.E.; Desimone, J.M. The Complex Role of Multivalency in Nanoparticles Targeting the Transferrin Receptor for Cancer Therapies. J. Am. Chem. Soc. 2010, 132, 11306-11313. [CrossRef]

67. Fan, K.; Jia, X.; Zhou, M.; Wang, K.; Conde, J.; He, J.; Tian, J.; Yan, X. Ferritin Nanocarrier Traverses the Blood Brain Barrier and Kills Glioma. ACS Nano 2018, 12, 4105-4115. [CrossRef]

68. Cui, C.; Cheng, X.; Yan, L.; Ding, H.; Guan, X.; Zhang, W.; Tian, X.; Hao, C. Downregulation of TfR1 Promotes Progression of Colorectal Cancer via the JAK/STAT Pathway. Cancer Manag. Res. 2019, 11, 6323-6341. [CrossRef] [PubMed]

69. Bhupanapadu Sunkesula, S.R.; Luo, X.; Das, D.; Singh, A.; Singh, N. Iron Content of Ferritin Modulates Its Uptake by Intestinal Epithelium: Implications for Co-Transport of Prions. Mol. Brain 2010, 3, 14. [CrossRef]

70. Brylinski, M.; Skolnick, J. What Is the Relationship between the Global Structures of Apo and Holo Proteins? Proteins 2008, 70, 363-377. [CrossRef] [PubMed] 
71. Clark, J.J.; Benson, M.L.; Smith, R.D.; Carlson, H.A. Inherent versus Induced Protein Flexibility: Comparisons within and between Apo and Holo Structures. PLoS Comput. Biol. 2019, 15, e1006705. [CrossRef] [PubMed]

72. Woolf, T.B.; Grossfield, A.; Tychko, M. Differences between Apo and Three Holo Forms of the Intestinal Fatty Acid Binding Protein Seen by Molecular Dynamics Computer Calculations. Biophys. J. 2000, 78, 608-625. [CrossRef]

73. Hunter, N.H.; Bakula, B.C.; Bruce, C.D. Molecular Dynamics Simulations of Apo and Holo Forms of Fatty Acid Binding Protein 5 and Cellular Retinoic Acid Binding Protein II Reveal Highly Mobile Protein, Retinoic Acid Ligand, and Water Molecules. J. Biomol. Struct. Dyn. 2018, 36, 1893-1907. [CrossRef] [PubMed] 